\title{
CHARACTERISTICS OF SERVICES AND THEIR CONSEQUENCES FOR THE STRATEGY OF SOCIAL RESPONSIBILITY
}

\author{
EDYTA SPODARCZYK
}

Akademia Morska w Gdyni, POLAND

e-mail: e.spodarczyk@wpit.am.gdynia.pl

\section{RECEIVED}

ACCEPTED

JEL

CLASSIFICATION

KEYWORDS

ABSTRACT

\author{
8 August 2017
}

15 December 2017

M14, M39

service, service features, CSR, social responsibility strategy

There are different approaches to social responsibility in practice of Polish companies. Apart from companies that have professionally developed social responsibility strategies linked to corporate DNA, there are also those that understand social responsibility mistakenly, identifying it with philanthropy, for example.

Adapting the corporate social responsibility strategy to the specific nature of an enterprises operations allows them to act responsibly and at the same time in the interests of their business. Therefore, the question arises about the nature of these activities and the so-called good practices in service companies. May the nature and characteristics of services (intangibility, diversity, inseparability, i) affect the development of social responsibility strategy and selection of good practices?

The aim of this article is to point to the consequences for the CSR strategy, resulting from the nature of the services. To realize this aim, author conducted literature study. Method of synthesis was used to inference.

\section{The service and its characteristics}

There are many definitions of the term "service" in the literature. The multitude of definitions and their diversity makes it difficult to grasp the essence of this notion.

The Polish language dictionary defines a service as "help shown to someone" or "business activity serving the needs of people" (Doroszewski, 1996). 
In marketing terms, the service next to a product, place, event, experience, organization, value, person, information and idea is the category of the product. The product, however, is the subject of marketing activities, which in its essence is a set of benefits to the customer (Kotler, Keller, 2012). To provide benefits to the customers and thus to meet their needs, apart from the knowledge of these needs, it is also necessary to understand what is the object of marketing, in this case - the service. A simple definition of the service, similar to the dictionary definition, is given by M. Pluta-Olearnik, who states that the service is the benefits offered for sell, essentially intangible and subjectively assessed by customers (Pluta-Olearnik, 1993).

$\mathrm{Ph}$. Kotler defines a service as any action that one party can offer to another; it is impenetrable and does not lead to any property. Its production may but does not have to be related to the physical product (Kotler, 1996).

In a similar manner, indicating that the service is an action (activity), it is defined by A. Payne. However, in Payn's terms, the service does not have to be completely intangible, it is sufficient that there is an element of immateriality. According to Payne, the service is any activity that incorporates an intangible element that involves the interaction of the customer or the object or property in his possession and which does not result in the transfer of ownership.

The transfer of the ownership may, however, take place and the provision of the service may or may not be closely related to the material good (Payne, 1997). The definition proposed by A. Payn on the one hand is very universal. It confirms T. Levitt's observation, that there is no such thing as a service industry. There are only industries that provide more or less services than others. They all provide services (Levitt, 1972). On other hand, such a broad view of the essence of the service may give the impression that the activities of manufacturing and service companies are not significantly different. What is the service? It may be intangible, but it may only contain an element of immateriality. It does not cause the transfer of ownership, but it is possible in some cases. Such an approach may contribute to erroneous decisions of managers who will not take into account the specificity of services in their decisions.

These definitions, according to the author, do not fully reflect the specificity of the service. They may provide the basis for theoretical considerations on the essence of the service, but from the perspective of the organization practice, their usefulness is reduced. Doubts about the nature of the services are largely dispelled by the concept of continuum proposed by G.L. Shostack (Shostack, 1982 for Mudie and Cotton, 1998). Shostack has developed a scale in which she has placed categories of products ordered from material products (products) to intangible products (services). Moving from the left to the right, the products lose their tangible, material character, until the opposite pole, there is no possibility to perceive the product by means of the sense of sight, touch, taste, hearing, smell.

By analyzing the concept of continuum, we can agree with T. Levitt's earlier opinion that the service is provided by everyone. In each offer the is (may be) intangible element. Apart from this, the organization should provide the client with the desired set of benefits. However, as the product loses its material character, the customer may find it increasingly difficult to make a choice. The reason for this is not just the intangible nature of the offer. Intangibility, in other words, is the cause of the remaining features of the service. By moving to the right side of the scale, characteristic features of services appear, such as diversity, inseparability and impermanence, and the previously mentioned intagiblity.

As mentioned above, the intangible nature of the service makes it impossible for a customer to assess the service before buying using the senses. Inseparability is a feature that is associated with the simultaneous 
production and consumption of the service (the process is often preceded by the sale of the service). In many cases the customer must participate in the process, as this is a condition for satisfying the need (eg legal advice). In a particular situation, a service can have specific effects for the body (eg hairdresser, masseur, doctor) or the customer's mind (eg education, psychotherapy) (Lovelock, Wirtz, 2011). What is more inseparability involves the contact of a person providing the service with a customer, and often the involvement of the customer in the service delivery process. Diversity means that it is difficult to standardize the services, preserve their uniformity and quality. Such variability of services is related, on one hand, to the person who provides the service, its competence, state (fatigue, nervousness, etc.), the time of service, and the way it is performed. On the other hand, the variability of services can be affected by the customer. Emotional state, physical condition and attitude of the buyer can affect the perception of the service. Services, due to their immateriality and inseparability, are generally unstable. They can not be stored or produced for stock.

The features of services evoke the implications in the strategy of service organization. In this area the activities of the organization are reduced to the limitation of these qualities because they are disadvantageous from the point of view of the organization and the customer (see Table 1).

Table 1 Characteristics of services and the limitation of their impact

\begin{tabular}{ll}
\hline $\begin{array}{l}\text { Features of the } \\
\text { service }\end{array}$ & \\
\hline Immateriality & Place (external and internal appearance of the organization). \\
& People (busy staff, adequate staff for quick service). \\
& Equipment (modern equipment). \\
& Information materials (folders, simulators, brochures, photos). \\
& Symbols (organization name, logo). \\
& Price \\
\hline Inseparability & Selection of employees. \\
& Staff training. \\
& Customers commitment to the production and delivery of the service requires the care of the way of production. \\
& Material certificates (place, equipment, etc.). \\
& Communication with the customer \\
\hline Variability & Selection of employees. \\
& Staff training. \\
& Motivating employees. \\
Introduction of procedures. \\
Partial automation of the service process. \\
Caring for the atmosphere in the organization. \\
Communication with the customer
\end{tabular}

Source: own study based on Mudi and Cotton (1998).

Customers who make a purchase decision are accompanied by uncertainty and risk, resulting from the lack of knowledge of what value they will actually receive, how it will be delivered, and the consequences of the decision. In fact, the customer must trust the service provider, his competencies, honesty and good will when selecting 
a service offering. Customers often risk the loss of material value. As examples can serve decisions about the usage of medical services (risk of loss of health or even life), financial (risk of loss of property, means of living) or legal (risk of loss of freedom, good name). In view of the above, the service organization and the people who on behalf of the organization provide services are responsible to customers. Many service companies are aware of this responsibility. Some of them include responsibility in their strategy or develop a strategy of social responsibility. The specificity of the CSR strategy in service companies will be discussed later in this article.

\section{Strategy of social responsibility}

The ISO 26000 Guidance on Social Responsibility, published by ISO International Organization for Standardization (ISO 26000), is an attempt to organize different approaches to define and interpret this concept. This standard is universal and can be used by various organizations (corporations, non-profit organizations, local governments, etc.). It defines the concept of social responsibility as "The organization responsibility for influencing its decisions and actions (products, services, processes) on society and the environment through transparent and ethical behaviour (www.odpowiedzialnafirma.pl/o-csr/iso-26000, lipiec 2017).

Despite the popularisation of the concept of social responsibility and consequently increasing awareness of its assumptions within the organization, the implementation of social responsibility in practice is still insufficient. ${ }^{1}$ The practices of many companies indicate that social responsibility is primarily just another way to build an image. Often, actions declared as socially responsible come down to occasional philanthropy or are simply necessary to stay on the market (such as ensuring product quality, quality of customer service, facilities for disabled customers, etc.). Few companies treat social responsibility as an integral part of the strategy (see Spodarczyk, SzelagowskaRudzka, 2015). The knowledge of the concept of social responsibility is varied. In many cases, good practices are the manifestation of the willingness to do something for a shared, social benefit. The problem is that, these benefits, as well as socially responsible activities in which companies are engaged, appear to be a coincidental. They are not related to business activities, so not always the benefits of the companies are those they expect and those that would be relevant to the problems and goals of the organization. It would be advisable to develop a model of CSR, which takes into account the specificity of the company which include the specifics of the company, with particular emphasis on the problems and strengths, and local character of the activity (cf. Spodarczyk, 2016).

By developing a CSR strategy, the following steps can be taken:

1. Define the problems to solve.

2. Identify where the areas of corporate social responsibility violate stakeholder interests.

3. In the context of defined problems formulate the goals to achieve.

4. Identify the benefits that can be achieved by resolving problems/achieving goals.

5. Choose areas of social responsibility based on point 1 and 2 .

6. Plan good practices that lead to the achievement of the chosen benefits.

7. Check if there is a possibility to get involved in the activities that have already started (see Spodarczyk, 2016).

The above approach will also allow to limit the barriers that entrepreneurs meet while implementing socially responsible activities. This particularly applies to the incurred costs and to the extra time spent by the owners and

${ }^{1}$ Critical evaluation of socially responsible practices has been included by the author in Spodarczyk (2011), pp. 5-18 
employees. It will happen because social responsibility will be an investment rather than a cost, a way to solve problems, and not an action detached from the problems of the enterprise.

\section{The implications for social responsibility strategy arising from the characteristics of the services}

The starting point for further action in the scope of corporate social responsibility should be an area of organizational order. This is where the role of corporate social responsibility in the organization is defined and the main principles of its functioning are defined. Good practices establish a corporate social responsibility strategy and its place in the practice of the company, and thus the role of top management in supporting the implementation of the strategy (see Lewicka-Strzałecka, 2006; Porter, Kramer, 2007; Adamczyk, 2009; Lenssen, 2009).

The author believes that the strategy of social responsibility should be synonymous with a declaration of fair and ethical business behaviour, as trust is particularly important in relation to customer-based relationships in the case of services. The customer is placing himself at the service provider disposal. It is the company and its employees who have the knowledge and skills necessary to meet the needs and expectations of the customer. Therefore, ethical attitudes and responsibilities for the actions and consequences of these actions should be expected from service companies and their employees. These expectations can be realized by good practices in the area of employee issues.

Practices in the area of employee and consumer issues should be subordinated to the principles of building relationships based on trust, partnership and respect. Values such as honesty, responsibility, customer care (including internal care), supported by competence, should be constantly promoted and practiced in corporate relationships. In service everything depends on people. It is important not to only write the above principles in the strategy. More important is to make them the real value for the chief executive/owners and allow them to influence the recruitment, training, communication and motivation processes. Only in this way can the organization ensure clear and ethical actions directed at consumers.

Thus, two main groups of stakeholders are emerging for service companies: employees and customers. Service providers are close to these stakeholders as socially responsible organizations can offer solutions that are not detached and have added value. These solutions, as previously mentioned, should take into account the characteristics of the service (intangibility, inseparability, diversity, instability) that are a problem for the buyer, which, among other things, contributes to the difficulty of managing the services. Due to the features of the service, when planning good practices it is worth taking into account some indications. Their aim is to limit the buyer/servicerelated risk and the consequences resulting from the usage of the service by:

1. Educating consumers (providing knowledge about both positive and negative consequences of sevice usage, indicating the criteria for choosing a particular service category). For this purpose, websites, leaflets and, above all, the knowledge and experience of employees, who should be motivated to communicate to their customers (even at the expense of customer resigning from the service if there are reasons for this) can be used.

2. Preparation of comprehensive, transparent, accessible and legible information within the material evidence of services. If there is a possibility of pre-post simulation, offer the client the option. Offer customers consultation in case of doubt.

3. Due to the inseparability of the provision and consumption of services, provide safety and comfort to both customers and employees. 
4. Awareness of the employee impact on quality of service and service should be the basis for offering attractive employment conditions to employees (contract of employment, adequate wages for employee involvement and competence, training system, working atmosphere, etc.). In many service industries the working conditions are unsatisfactory, and this indirectly contributes to customer discontentment.

5. Employment of competent staff and continuous care for their qualifications. Training and motivation of employees should not only be focused on their substantive competence, but also on the very important social competence of their service contacts. Employees should be also aware of their responsibility. Ethical principles should be reflected not only in ethical codes, but also in procedures and values represented by employees.

6. The diversity of services is a consequence of so-called human factor. It is affected by both the customer and the employee. The company should ensure such working conditions to keep employees in good physical and mental condition and provide services responsibly. Working hours should be observed. If demand increases (there is a problem of instability of service), additional staff should be employed.

\section{Conclusionos}

The interest of service companies, in the concept of social responsibility should be the consequence of the transfer of values that are important for owners and employees to the company. Social responsibility should not only be the result of business calculations, but the consequence of translating the principles, values and needs of the owners and employees into the character of the business. In service companies, it is particularly important to build relationships between the company and its stakeholders (Rizan, Warokka, Listsawati, 2014; Glimore, 2006; Zinkhan, 2002; Dembińska-Cyran, Holub-Iwan, Perenc, 2004). Due to the specificity of the service company and the features of the service, the relationships that the company builds with customers and employees are becoming increasingly important. Mentioning the business relationships (company-customer, company-employee) it can not be forgotten that attracting a customer or employing a worker creates a relationship, the interdependence that the parties should feel responsible for. The relationship is based on the principles found by the parties. The parties enter into relationships because they expect certain benefits and mutual respect for rights and needs. It is also interesting to know the interplay between these relationships. The nature of the company-employee relationship directly influences on employee-customer relationships and customer-company relationships. Hence, in the corporate social responsibility strategy, areas of good governance, employment, and consumer issues are important fields for good practices. The strategy should be designed in such a way, that within good practices, reduce the customer risk arising from the features of the service through responsible decisions regarding employment policy, customer education, and internal and external communication.

\section{References}

Adamczyk, J. (2009). Społeczna odpowiedzialność przedsiębiorstw. Warszawa: PWE.

Dembińska-Cyran, I., Hołub-Iwan, J., Perenc J (2004). Zarządzanie relacjami z klientem. Warszawa: Diffin.

Doroszewski, W. (ed.) (1996). Dictionary of Polish Language. Volume IX. Warszawa: PWN.

Gilmore, A. (2006). Usługi. Marketing i zarządzanie. Warszawa: PWE.

Kotler, Ph. (1996). Marketing. Analyzing, Planning, Implementing and Controlling. Warszawa: Gebethner \& Ska

Kotler, Ph., Keller, K.L. (2012). Marketing. Poznań: REBIS. 
Levitt, T. (1972). Production-line Approach to Service. Retrieved from: https://hbr.org/1972/09/production-line-approach-to-service. Lewicka-Strzałecka, A. (2006). Odpowiedzialność moralna w życiu gospodarczym. Warszawa: IFiS PAN.

Lovelock, Ch., Wirtz, J. (2011). Marketing Services. People, Technology, Strategy. New Jersey: Prentice Hall

Mudie, P., Cotton, A. (1998). Usługi. Zarządzanie i Marketing. Warszawa: Wydawnictwo Naukowe PWN.

Payne, A. (1996). Marketing usług. Warszawa: PWE.

Pluta-Olearnik, M. (1993). Marketing usług. Warszawa: PWE.

Porter, M.E., Kramer, M.R. (2007). Strategia a społeczeństwo: społeczna odpowiedzialność biznesu - pożyteczna moda czy nowy element strategii konkurencyjnej? In: Sekrety skutecznych strategii. Harvard Business Review Polska.

Rizan, M., Warokka, A., Devi Lettyati, D. (2014). Relationship Marketing and Customer Loyalty : Do Customer Satisfaction and Customer Trust Really Serve as Intervening Variables? Journal of Marketing Research and Case Studies, 2014.

Smith, N.C., Lenssen, G. (eds.) (2009). Mainstreaming Corporate Responsibility : Cases and Text for Integrating Corporate Responsibility across the Business School Curriculum. New Jersey: Wiley.

Spodarczyk, E. (2011). Społeczna odpowiedzialność przedsiębiorstwa wobec konsumentów. Studia przypadków. Zarządzanie i Edukacja, 76/77.

Spodarczyk, E. (2016). The Concept of Corporate Social Responsibility in the Micro and Small Enterprise Sector. Proceedings of the 12th European Conference on Management Leadership and Governance. Bukareszt: ECMLG.

Spodarczyk, E., Szelagowska-Rudzka, K. (2015). Is Social Responsibility Required in the Cooperation Among Universities, Businesses and Local Government in the Local Environment? Proceedings of the 11th European Conference on Management Leadership and Governance. Lizbona: ECMLG.

www.odpowiedzialnafirma.pl/o-csr/iso-26000.

Zinkhan, G.M. (2002). Relationship Marketing: Theory and Implementation. Journal of Market-Focused Management, 2 (5). DOI: 10.1023/A:1014031025271.

Cite this article aS: Spodarczyk, E. (2018). Characteristics of Services and their Consequences for the Strategy of Social Responsibility. European Journal of Service Management, 1 (25), 289-295. DOI: 10.18276/ejsm.2018.25-35. 